\title{
STABILITY ANALYSIS OF ISLAMIC BANKING: INDONESIA, MALAYSIA AND PAKISTAN
}

\author{
Luqmanulhakim Luqmanulhakim*, Ronald Rulindo, Saiful Anwar \\ Bank Syariah Indonesia (BSI), Lembaga Penjamin Simpanan (LPS) Indonesia, \\ Institut Teknologi dan Bisnis Ahmad Dahlan Jakarta, Indonesia \\ luqmania@gmail.com,rulindoku@gmail.com,dr.saiful@qmail.id
}

https://doi.org/10.46367/iqtishaduna.v10i1.326

Received: Apr 25, 2021 Revised: Jun 21, 2021 Accepted: Jun 25, 2021 Published: Jun 29, 2021

\begin{abstract}
Following the 2008 financial crisis, the global economy will continue to experience shock in the years to come. Therefore, it is vital to conduct research that can anticipate the impact of fluctuations in financial stability. This research examines the stability of the Islamic banking system in Indonesia, Malaysia, and Pakistan, using Z-Score as a proxy variable for stability measurement and Markov Switching VAR for the method. The objectives are to identify which Islamic banking has better resilience in facing crisis and identify the economic variables that have a significant effect on the stability of Islamic banking. The results showed that the stability of Indonesian Islamic banking was more stable compared to Malaysia and Pakistan. The crisis periods determined from the method show that in 2019 all countries studied entered the beginning of the crisis period, which means the world conditions tend to re-enter the crisis, repeating the 2008 financial crisis.
\end{abstract}

Keywords: Banking Stability, Z-Score, Markov Switching, MS-VAR.

\section{INTRODUCTION}

The banking industry dominates the intermediary role of financial institutions, wherein Indonesia the banking industry controls about $80.75 \%$ of the total assets in the financial industry. The Malaysian banking industry controls about $50.6 \%$ of the total assets in the financial industry. The banking industry in Pakistan controls $59 \%$ of the total assets in the financial industry (International Monetary Fund 2017). This explains that the banking industry in these three countries still dominates compared to other financial industries, including Islamic banking. Moreover, globally the composition of Islamic banking controls about $76 \%$ of the total assets of the Islamic financial industry worldwide, followed by Sukuk at $19.5 \%$, then Islamic funds at $3.3 \%$. Finally, the Takaful industry has assets of 1.3\% (Islamic Financial Services Industry 2018).

It is imperative to conduct research on Islamic finance and banking, which can be used as input for decision-makers, especially those related to the Islamic banking industry in various countries, in order to formulate steps to anticipate financial crises that can affect the Islamic banking industry. This research should provide an accurate picture of financial crisis predictions that may occur in the future. The research also needs to take a sample of countries representing the 
Islamic banking industry which is representative enough to represent Islamic banking in the world. The top three countries referring to Mukhlisin and Komalasari (2018) research are Malaysia, Pakistan, and Indonesia, which is relevant. Based on the economic growth data in the three countries used as research, economic growth in 2019 began to decline. This can be seen as a sign that a recession is coming. Trends in economic growth data like this will lead to unstable economic conditions and high levels of volatility that will affect the banking sector in Indonesia, Malaysia, and Pakistan (Figure 1).

\section{Figure 1 Economic Growth of Indonesia, Malaysia and Pakistan 2011-2019}

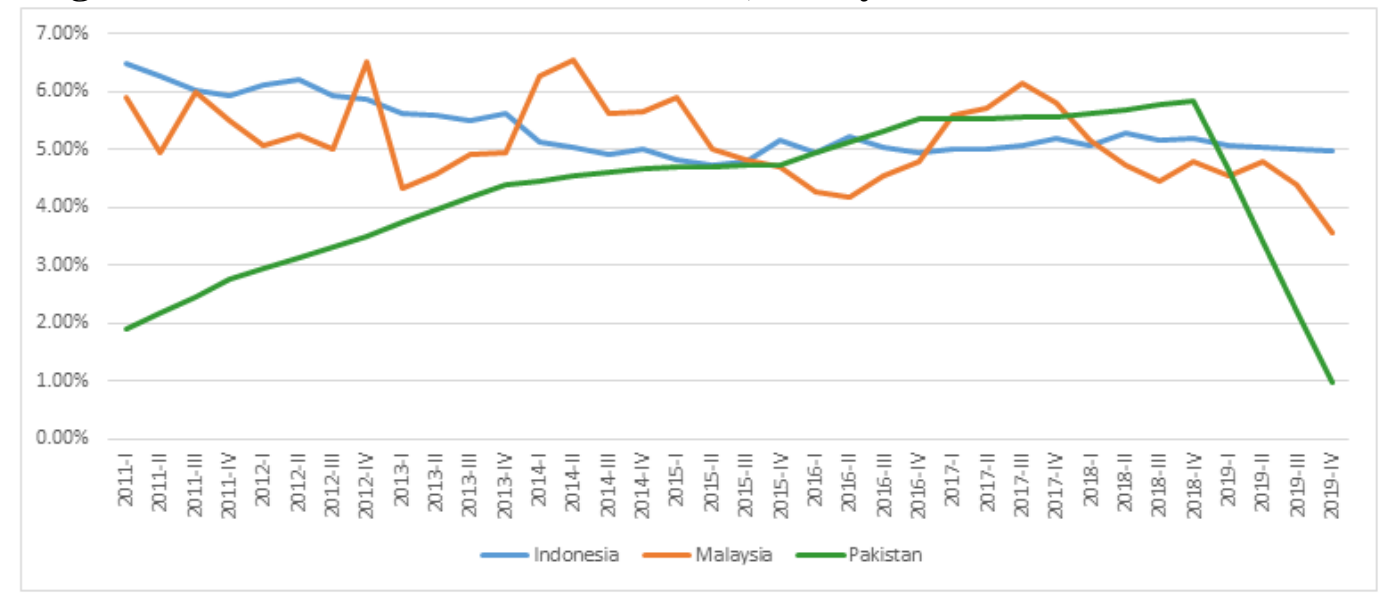

Source: BPS Indonesia and www.macrotrend.net, processed data

Previous studies have discussed a lot about the stability of Islamic banking in this study to see the level of stability of Islamic banking against internal and external shocks with several indicators studied. Nurfalah et al. (2018) examined conventional banking and Islamic banking in Indonesia, the results of which explained that the significant stability indicators of Islamic banking were bank deposits and CA/GDP. Zahra, Ascarya, and Huda (2018) examined the measurement of the stability of conventional banking and Islamic banking in Indonesia, wherewith the Z-score indicator Islamic banking is more stable than conventional banking. Rahim and Zakaria (2013) examined the stability of Islamic banking and conventional banking with a case study of the Malaysian state, using the Z-Score and NPL indicators as proxy indicators of banking stability. Čihák and Hesse (2010) examine the stability of Islamic banking and conventional banking using the proxy indicator Z-Score, where macroeconomic variables significantly affect financial system stability. Belouafi, Bourakba, and Saci (2015) examine the research literature that discusses Islamic finance and finance, where the Z-Score indicator is the most commonly used proxy to measure the stability of Islamic financial intermediaries. The first four studies mentioned above all use ZScore as proxy indicators of banking stability and use the Markov Switching model as a research tool, but only use one country sample. The last study mention above confirms that $\mathrm{Z}$-Score is the most common proxy indicator.

The study aims to analyze the effect of economic shocks on the stability of Islamic banking in Indonesia, Malaysia, and Pakistan. Analyze the comparison of the level of stability of Islamic banking in the three countries in the face of economic shocks, using Z-Score as proxy indicators of banking stability and the 
Markov Switching model as a research tool. Then to identify which is the most stable to the economics volatility or has better resilience in facing crisis and to identify the economic variables that have a significant effect on the stability of Islamic banking. This study also determines the period of crisis of the Islamic banking industry in Indonesia, Malaysia, and Pakistan, which has never been researched before, so that it can help regulators, industry players, and academics design anticipatory steps in detail to overcome the impact of fluctuations in financial stability, especially in the Islamic banking industry.

\section{LITERATURE REVIEW}

Financial system stability is a condition in which the economy is in good condition and is not affected by the economic crisis. Schinasi (2004) defines financial system stability as the capability of the financial system in (1) Facilitating efficient allocation of economic resources both spatially and in particular over time as well as the effectiveness of other economic processes such as wealth accumulation, economic growth, and social welfare; (2) Assessing prices and allocating them and managing financial risks; and (3) Maintains its ability to stabilize even when it is affected by external shocks or by increasing imbalances mainly through self-corrective mechanisms. Some researchers define financial stability as a condition in which the economic situation is stable and does not damage the economy due to financial instability (Crockett 1996; Davis 2003), especially when information problems damage the ability of the financial system to allocate funds for productive investment opportunities (Mishkin 2012).

Financial system stability differs from monetary stability. Financial system stability is more about the stability of the intermediary role of financial institutions and market stability in the financial market. In contrast, monetary stability refers to price stability in the form of currency stability. Financial system stability is difficult to define and measure, so there is no standard definition of financial system stability (Schinasi 2004; Houben, Kakes, and Schinasi 2004; Allen, and Wood 2005). In contrast to monetary stability, which refers to price stability and price, stability is identical to the inflation rate. The conventional view illustrates that inflation is the main factor that creates financial instability. Another view holds that price stability will improve financial stability, and this is based on the historical situation where banking crises often occur during recessions after periods of high inflation (Issing 2003).

Čihák (2006) explains that there are several divisions of objectives that are at the core of achieving financial system stability and other policies, two of them namely (1) macroeconomics aims at stability and growth and development, (2) macroprudential aims at financial stability. This division of objectives will have an impact on decision and policy making when there is a systemic risk that causes economic instability, and this also underlies the research of Islamic banking stability analysis.

Based on Čihák's explanation regarding macroeconomics and macroprudential which are closely related to financial system stability, the author suspects that the stability of Islamic banking in Indonesia is more stable than the stability of Islamic banking in the other two countries, and the economic variables 
that significantly affect the level of stability of Islamic banking in Indonesia are less than significant economics variables in the other two countries.

\section{METHODS}

The research will be conducted by analyzing secondary data using the Markov Switching (MS) approach. In principle, this MS model uses the MS Autoregressive Model developed by Hamilton (1990). This study uses a latent variable that follows the first derivative from two-stage Markov, which is $\left\{S_{t}\right\}=$ 1. $\mathrm{S}_{\mathrm{t}}=1$ in the crisis state and $\mathrm{St}=0$ in the tranquil state.

This study uses secondary data obtained from official sources and monthly from January 2008 to December 2018. Sources of Indonesian Islamic banking data are obtained from the Indonesian Banking Statistics, Financial Services Authority (SPI-OJK), Islamic Banking Statistics, Financial Services Authority (SPS-OJK), the Central Bureau of Statistics (BPS), Bank Indonesia Economic and Monetary Statistics (SEKI-BI) and International Financial Statistics (IFS) published by the IMF. Data sources for Malaysian Islamic banking were obtained from the State Bank of Malaysia (BNM), and data sources for Islamic banking in Pakistan were obtained from the State Bank of Pakistan (SBP). Meanwhile, world crude oil price data is obtained from the US Energy Administration Information, and the Fed's interest rate data is obtained from the IMF and World Bank. There are three general equations used in this research, namely the Indonesian Islamic banking equation, the Malaysian Islamic banking equation and the Pakistani Islamic Banking equation (Table 1).

\section{Table 1 General Equations of Research Model}

\begin{tabular}{|c|c|}
\hline $\begin{array}{l}\text { Model 1: } \\
\text { Indonesia }\end{array}$ & $\begin{array}{l}\text { Z-score } I_{t}=A_{0}+A_{1} C_{A R}^{t-i}+A_{2} C_{t-j}+A_{3} N F_{t-k}+A_{4} F R_{t-1}+A_{5} E C_{t-} \\
m\end{array}$ \\
\hline $\begin{array}{l}\text { Model 2: } \\
\text { Malaysia }\end{array}$ & 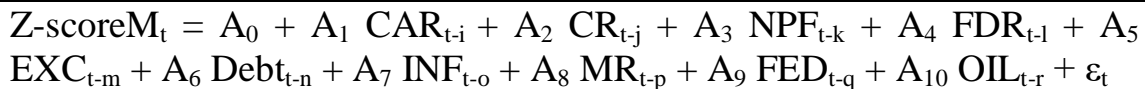 \\
\hline $\begin{array}{l}\text { Model 3: } \\
\text { Pakistan }\end{array}$ & $\begin{array}{l}\text { Z-scoreP } \mathrm{t}_{\mathrm{t}}=\mathrm{A}_{0}+\mathrm{A}_{1} \mathrm{CAR}_{\mathrm{t}-\mathrm{i}}+\mathrm{A}_{2} \mathrm{CR}_{\mathrm{t}-\mathrm{j}}+\mathrm{A}_{3} \mathrm{NPF}_{\mathrm{t}-\mathrm{k}}+\mathrm{A}_{4} \mathrm{FDR}_{\mathrm{t}-\mathrm{l}}+\mathrm{A}_{5} \mathrm{EXC}_{\mathrm{t}-} \\
\mathrm{m}+\mathrm{A}_{6} \text { Debt }_{\mathrm{t}-\mathrm{n}}+\mathrm{A}_{7} \mathrm{INF}_{\mathrm{t}-\mathrm{o}}+\mathrm{A}_{8} \mathrm{PR}_{\mathrm{t}-\mathrm{p}}+\mathrm{A}_{9} \mathrm{FED}_{\mathrm{t}-\mathrm{q}}+\mathrm{A}_{10} \mathrm{OIL}_{\mathrm{t}-\mathrm{r}}+\varepsilon_{\mathrm{t}}\end{array}$ \\
\hline
\end{tabular}

The variable used in this study as a measure of stability is the Z-Score. Many researchers use this variable as an indicator to determine banking stability. The banking sector will experience bankruptcy and even crisis if the percentage of assets is lower than the percentage of the loan value. Meanwhile, the Z-score formula is a function of total equity/total assets plus the average Returns on Assets (ROA) divided by the standard deviation of ROA. The equation is $\mathrm{Z} \equiv(\mathrm{k}+$ $\mu) / \sigma$. In Boyd, Nicolo, and Jalal (2009) research, it is explained in more detail where the Z-score is the sum of ROA and Equity to Asset (EA) divided by the standard deviation of ROA. The equation is: $\mathrm{Z}=(R O A+\mathrm{EA}) / \sigma \mathrm{ROA}$. In addition, the economic indicators used in this research are FDR, CR, CAR, NPF, EXC, DEBT, INF, IR, FED, and OIL. The definitions of the stability proxy indicator and economic indicators are presented in Table 2. 
Table 2 Summary of Indicators Used in the Research

\begin{tabular}{ll|ll}
\hline Z-ScoreI & \multicolumn{4}{l}{ Indonesian Islamic Banking Stability Indicator } \\
Z-ScoreM & \multicolumn{2}{l}{ Malaysian Islamic Banking Stability Indicator } \\
Z-ScoreP & Pakistani Islamic Banking Stability Indicator \\
\hline FDR & Financing to Deposit Ratio & DEBT & Total Debt \\
CR & Current Ratio & INF & Inflation Rate \\
CAR & Capital Adequacy Ratio & IR/MR/PR & Interest Rate \\
NPF & Non Performing Financing & FED & Fed Rate \\
EXC & Exchange Rate & OIL & Oil Price \\
\hline
\end{tabular}

Source: author's modification

The Markov Switching Model (also known as the regime-switching model) is one of the most popular nonlinear time series models. This model involves multiple structures (equations) that can characterize the time series behaviors in different regimes. The regime is the term used to describe structural changes in time series data, i.e., a shift in the time series behavior due to some permanent change in the economy's structure. The variable used as the indicator for banking stability is the Z-Score $\left(\mathrm{y}_{\mathrm{t}}\right)$. In this research, the Markov Switching model used is the multivariate model i.e. Model MS-VAR (Markov Switching Vector Auto Regression) which can be used as an alternative for time series linear model with constant parameter. According to Krolzig (1997, 6-7), the general idea of this regime-change model is that the parameter of the time series vector having dimension $\mathrm{K}\left\{y_{t}\right\}$ depends upon an unobserved regime variable $s_{t} \in\{1, \ldots, m\}$, which represents the probability of being in a specific regime.

This research uses the latent variable, which follows the first derivation from the two-stage Markov. The $S_{t}=1$ is the crisis state, and the $S_{t}=0$ is the tranquil state. The dependent variable $\left(\mathrm{Y}_{\mathrm{t}}\right)$ used in this research is the $\mathrm{Z}$-Score. In this MS model, the value of the mean and the variance of $Y_{t}$ can change depending on the regime. The estimation procedure used is by maximizing the function of likelihood. The function of likelihood is measured by the iteration suggested by Hamilton (1990).

\section{RESULTS AND DISCUSSION}

\section{Comparison of Z-Score Variable}

In this study, the authors use indicators of stability in Islamic banking, which refer to Čihák and Hesse (2010), namely the Z-Score. The Z-Score value is obtained from the data component of the total equity / total asset function plus the average Return on Assets (ROA) divided by the standard deviation of ROA, which is written with the formula $Z \equiv(k+\mu) / \sigma$ (Čihák and Hesse 2010). Boyd, Nicolo, and Jalal (2009) explain in more detail where the Z-Score is the sum of ROA and Equity to Asset (EA) divided by the standard deviation of ROA, which is written with the formula $\mathrm{Z}=(\mathrm{ROA}+\mathrm{EA}) / \sigma \mathrm{ROA}$.

The results of the Z-Score data processing with $\sigma$ ROA from the overall data in this study indicate that the average Z-Score of Indonesian Islamic Banking is higher than the two other countries. As a result, Islamic Banking Malaysia occupies the second position, and the last position is Islamic Banking Pakistan. The average Z-Score of Indonesia is 14.19 , then the average Z-Score of Malaysian 
Islamic Banking is 10.94, and the average Z-Score of Islamic Banking in Pakistan is 7.33 (Figure 2).

Figure 2 Graphs of Average Z-ScoreI, Z-ScoreM and Z-Score-P

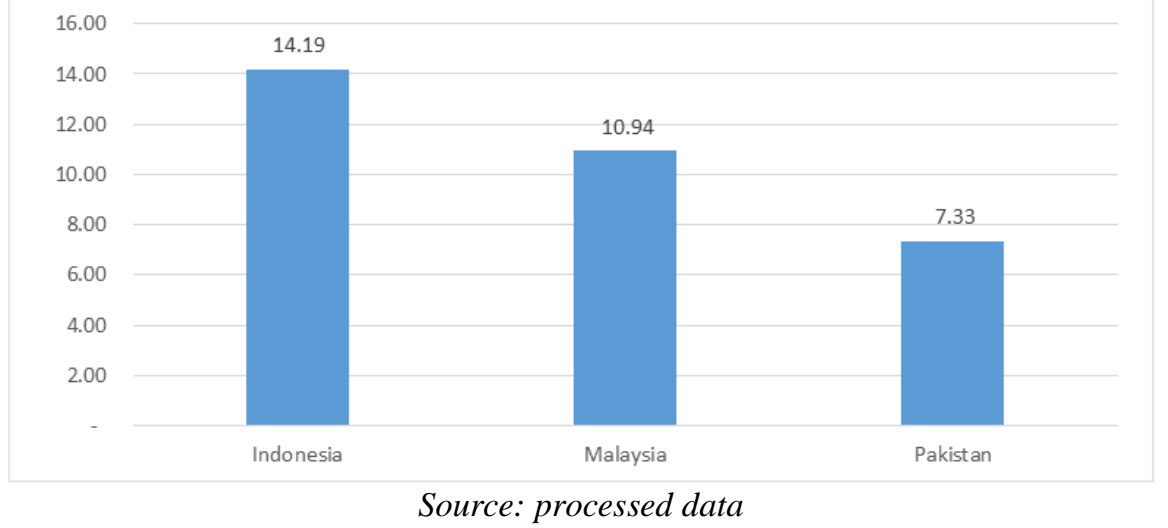

According to Čihák and Hesse (2010), a higher Z-Score value implies a lower risk of bankruptcy (insolvency). Therefore, based on data processing results, Indonesia has a higher average $\mathrm{Z}$-score, which means that Indonesian Islamic Banking has a higher level of stability and has a lower risk of bankruptcy than Malaysia and Pakistan. Meanwhile, Malaysian Islamic Banking has an average Z-Score, which is higher than Pakistani Islamic Banking, meaning that Malaysian Islamic Banking has a higher level of stability and has a lower risk of bankruptcy than Pakistani Islamic Banking.

This research used Markov Switching Vector Autoregression (MS-VAR) method in which some supporting tests were conducted. Those tests were the Stationary test (Gujarati 2003), the Heteroscedastic test, the Chow Breakpoint test, the EM Algorithm test (Borman 2004), and the Partial Significance test (Appendices).

\section{Interpretation of Estimated Result}

The different results were produced from the Indonesian Islamic Banking Model, Malaysian Islamic Banking Model, and Pakistani Islamic Banking Model. As previously discussed, the partial significance of the variables in accordance with the Partial Significance test shows five significant variables for the Indonesian Islamic Banking Model, namely NPF, FDR, EXC, DEBT, and INF.

Based on Table 3, a negative NPF coefficient value is -0.41 , and this means that an increase in NPF of 1 percent will reduce the level of stability of Islamic banking in Indonesia by 0.41 percent. This result follows the theory in which NPF is one of the indicators taken into account in measuring the soundness of a bank's assets. If the NPF value is high, the level of financing / bad credit is high, which will disrupt the bank's liquidity level. These results are consistent with previous research, namely Hosni (2014).

A negative FDR coefficient value is -46.33 , and this means an increase in FDR by 1 percent will reduce the stability of Islamic banking in Indonesia by 46.33 percent. This result is following the theory in which FDR is one of the indicators taken into account in measuring the soundness of a bank's assets and is 
included in the liquidity ratio of Islamic banking. If the FDR value of a bank is getting higher, it indicates that the liquidity capacity of the bank is getting lower. This is because the amount of funds required for financing is getting bigger. This result are in line with previous research conducted by Hardy and Pazarbaşioğlu (1999); Kassim and Majid (2010); Hidayat and Abduh (2012); Asanovic (2013).

Table 3 Coefficient Variables of Indonesian Islamic Banking Model

\begin{tabular}{ccc}
\hline Microeconomics Variable & Coefficient & t-Values \\
\hline CAR & -44.08 & -4.71 \\
CR & 3.76 & 3.08 \\
NPF & $\mathbf{- 0 . 4 1 *}$ & $\mathbf{- 0 . 1 0 *}$ \\
FDR & $\mathbf{- 4 6 . 3 3 *}$ & $\mathbf{- 1 . 4 0 *}$ \\
\hline Macroeconomics Variable & Coefficient & $\mathbf{t}-$ Values \\
\hline EXC & $\mathbf{- 0 . 1 6}^{*}$ & $\mathbf{- 0 . 7 5 *}$ \\
DEBT & $\mathbf{- 0 . 0 2}^{*}$ & $\mathbf{- 0 . 1 6 *}$ \\
INF & $\mathbf{- 5 . 2 6}$ & $\mathbf{- 1 . 0 2 *}$ \\
IR & -4.21 & -2.61 \\
\hline Global Variable & Coefficient & $\mathbf{t}-$ Values \\
\hline FED & -1.04 & -2.76 \\
OIL & 1.48 & -2.14 \\
\hline
\end{tabular}

Note: Numbers with $(*)$ are significant to real level of $5 \%$ with t-value between $-1,645$ and 1,645. Source: processed data

A negative EXC coefficient value is -0.16 , and this means an increase in EXC of 1 percent will reduce the level of stability of Islamic banking in Indonesia by 0.16 percent. The definition of an increase in EXC is the depreciation of the Indonesian Rupiah exchange rate against the United States Dollar, and this will make the prices of imported goods more expensive. If the bank has transactions or debt in dollars, the rate of return expense is due when the exchange rate depreciates more and more high. These results are in line with previous studies, namely Hardy and Pazarbaşioğlu (1998); Hardy and Pazarbaşioğlu (1999); Kaminsky and Reinhart (1999); Hagen and Ho (2007); Vargas (2009); Ascarya and Yumanita (2009); Ascarya and Syarifuddin (2012); Hosni (2014).

A negative DEBT coefficient value is -0.02 , and this means that an increase in DEBT of 1 percent will reduce the stability level of Islamic banking in Indonesia by 0.02 percent. This variable is closely related to the exchange rate. Systemically, if the total Indonesian government debt is getting higher and the Rupiah exchange rate depreciates, then the debt repayment burden will be even higher. On the other hand, the prices of goods and services will increase, so the monetary solution increases interest rates. However, this increase in interest rates will also impact the return of public financing. This result is following the theory in which increased debt will reduce Islamic banking stability in Indonesia. These results are in line with previous studies, namely Hardy and Pazarbaşioğlu (1999); Vargas (2009); Barişik, and Tay (2010); Hosni (2014). Furthermore, INF is one of the variables in this study that shows its significance level for the stability of Islamic banking in Indonesia.

A negative INF coefficient value is -5.26 , which means that an increase in INF by 1 percent will reduce the stability of Islamic banking in Indonesia by 5.26 percent. This result follows the theory in which an increase in inflation is marked by an increase in the prices of goods and services. People's ability to access financing in Islamic banking is affected by the decline, and the stability of Islamic 
banking is also decreasing. These results are consistent with several previous studies, namely Hardy and Pazarbaşioğlu (1998); Hardy and Pazarbaşioğlu (1999); Hagen and Ho (2007); Barişik and Tay (2010); Ascarya and Syarifuddin (2012).

Table 4 Coefficient Variables of Malaysian Islamic Banking Model

\begin{tabular}{ccc}
\hline Microeconomics Variable & Coefficient & t-Values \\
\hline CAR & $\mathbf{3 . 0 5}^{*}$ & $\mathbf{1 . 3 2}^{*}$ \\
CR & $\mathbf{0 . 1 4}^{*}$ & $\mathbf{0 . 1 2}$ \\
NPF & 2.58 & 1.97 \\
FDR & -19.25 & -1.83 \\
\hline Macroeconomics Variable & Coefficient & t-Values \\
\hline EXC & $\mathbf{- 0 . 0 0 1 6 *}^{*}$ & $\mathbf{- 0 . 0 0 8 *}$ \\
DEBT & 12.92 & 8.11 \\
INF & $\mathbf{- 4 . 9 8}^{*}$ & $\mathbf{- 1 . 0 0 4}$ \\
MR & $\mathbf{- 0 . 5 8}^{*}$ & $\mathbf{- 0 . 8 7 ^ { * }}$ \\
\hline Global Variable & Coefficient & t-Values \\
\hline FED & $\mathbf{- 0 . 3 8 *}$ & $\mathbf{- 0 . 4 8 *}$ \\
OIL & 2.34 & -3.80
\end{tabular}

Note: Numbers with $(*)$ are significant to real level of $5 \%$ with t-value between $-1,645$ and 1,645 . Source: processed data

As previously discussed, the partial significance of the variables following the Partial Significance test shows six significant variables for the Malaysian Islamic Banking Model, namely CAR, CR, EXC, IF, IR and FED. Based on Table 4 , a positive CAR coefficient value is 3.05 , which means that an increase in CAR of 1 percent will increase the stability of Islamic banking in Malaysia by 3.05 percent. This result follows the theory in which CAR is one of the indicators taken into account in measuring the soundness of a bank's assets. Calculation of banking CAR, namely by dividing the capital of a bank divided by risk-weighted assets (RWA), meaning that the higher the RWA, the lower the resulting CAR value and vice versa, the higher the capital of Islamic banking, the higher the CAR value of Islamic banking. Lack of capital adequacy for Islamic banking, which high RWA marks, can cause Islamic banking risk going bankrupt due to lack of capital. These results are consistent with several previous studies, namely Hardy and Pazarbaşioğlu (1999); Hidayat and Abduh (2012).

A positive CR coefficient value is 0.14 , which means that an increase in CR by 1 percent will increase the stability of Islamic banking in Malaysia by 0.14 percent. This result follows the theory in which CR is one of the indicators taken into account in measuring the soundness of a bank's assets and is included in the liquidity ratio of Islamic banking. The $\mathrm{CR}$ calculation is obtained from the division between current assets and current liabilities borne by Islamic banking. If the total cash of Islamic banking is fixed while the total liabilities increase, it will decrease the value of $\mathrm{CR}$ and vice versa if the total cash of Islamic banking increases while total liabilities are fixed or even decreases, the $\mathrm{CR}$ value will increase. The increase and decrease in the value of CR will result in the ability of Islamic banking to provide cash for liquidity. If the CR value of a bank is higher, it indicates that the liquidity capacity of the bank is getting higher too. However, if the $\mathrm{CR}$ value decreases, the liquidity capacity will decrease, which will be 
dangerous in bank-run conditions. This result is following previous research, namely Hardy and Pazarbaşioğlu (1999).

A negative EXC coefficient value is -0.0016 , which means that an increase in EXC of 1 percent will reduce the stability level of Islamic banking in Malaysia by 0.0016 percent. The definition of an increase in EXC is the depreciation of the Malaysian Ringgit exchange rate against the United States Dollar, and this will make the prices of imported goods more expensive. If the bank has transactions or debts in dollars, the rate of return is due when the exchange rate depreciates more and more highs. These results are in line with previous studies, namely Hardy and Pazarbaşioğlu (1998); Hardy and Pazarbaşioğlu (1999); Kaminsky and Reinhart (1999); Hagen and Ho (2007); Vargas (2009); Ascarya and Yumanita (2009); Ascarya and Syarifuddin (2012); Hosni (2014).

A negative INF coefficient value is -4.98 , which means that an increase in INF by 1 percent will reduce the stability level of Islamic banking in Malaysia by 4.98 percent. This result follows the theory in which an increase in inflation is marked by an increase in the prices of goods and services so that people's ability to access financing in Islamic banking is also affected by the decline and the stability of Islamic banking. This result is in accordance with several previous studies, namely Hardy and Pazarbaşioğlu (1998); Hardy and Pazarbaşioğlu (1999); Hagen and Ho (2007); Barişik and Tay (2010); Ascarya and Syarifuddin (2012).

A negative MR coefficient is -0.58 , which means that an increase in MR of 1 percent will reduce the stability level of Islamic banking in Malaysia by 0.58 percent. This variable can directly affect the stability of Islamic banking in Malaysia because high interest rates can increase the risk of debtors' failure to pay their financing. The risk of failure to pay will also increase the NPF value of Islamic banking, thereby disrupting the stability of Islamic banking in Malaysia. These results are in line with previous studies, namely Hardy and Pazarbaşioğlu (1998); Hardy and Pazarbaşioğlu (1999); Ascarya and Yumanita (2009); Kassim and Majid (2010); Akhtar, Abbas, and Toor (2011).

Furthermore, the global variable that affects the stability of Islamic banking in Malaysia is the FED. The negative FED coefficient value is -0.38 , which means that an increase in FED of 1 percent will reduce the stability level of Islamic banking in Malaysia by 0.38 percent. This result follows the theory where an increase in the FED rate will make the possibility of capital outflow from Malaysia and impact foreign direct investment such as stocks. When investment in shares in Malaysia does not attract investors because the returns from the FED rate are more attractive, the dominant effect is that the company lacks capital for business expansions, products become increasingly scarce in the market resulting in increased inflation. The solution is anticipating an increase in inflation is to increase interest rates; however, if interest rates increase again, it will result in the risk of default by the debtor. These results are consistent with several previous studies, namely Hardy and Pazarbaşioğlu (1999); Zhuang (2005).

As previously discussed, the partial significance of the variables following the Partial Significance test shows seven significant variables for the Pakistani Islamic Banking Model, namely CAR, CR, NPF, FDR, INF, PR, and OIL. Based on Table 5, the positive CR coefficient value is 5.90, which means that an increase in CR by 1 percent will increase the stability of Islamic banking in Pakistan by 
5.90 percent. This result follows the theory in which CR is one of the indicators taken into account in measuring the soundness of a bank's assets and is included in the liquidity ratio of Islamic banking. The increase and decrease in the value of $\mathrm{CR}$ will result in the ability of Islamic banking to provide cash for liquidity. If the $\mathrm{CR}$ value of a bank is higher, it indicates that the liquidity capacity of the bank is getting higher too. However, if the CR value decreases, the liquidity capacity will decrease, and it can be dangerous in bank-run conditions.

\begin{tabular}{|c|c|c|}
\hline Microeconomics Variable & Coefficient & t-Values \\
\hline CAR & $-19.17^{*}$ & $-1.33 *$ \\
\hline $\mathrm{CR}$ & $5.91 *$ & $1.52 *$ \\
\hline NPF & $3.16^{*}$ & $0.48 *$ \\
\hline FDR & $159.46 *$ & $1.32 *$ \\
\hline Macroeconomics Variable & Coefficient & t-Values \\
\hline EXC & -0.68 & -1.66 \\
\hline DEBT & 0.51 & 2.00 \\
\hline INF & $-14.42 *$ & $-0.57 *$ \\
\hline PR & $12.20 *$ & $1.15^{*}$ \\
\hline Global Variable & Coefficient & t-Values \\
\hline FED & -11.70 & -4.87 \\
\hline OIL & $-1.25 *$ & $-0.59 *$ \\
\hline
\end{tabular}

A negative EXC coefficient value is -0.68 , which means that an increase in EXC of 1 percent will reduce the stability level of Islamic banking in Pakistan by 0.68 percent. A negative INF coefficient value is -14.42 , which means that an increase in INF by 1 percent will reduce the stability level of Islamic banking in Pakistan by 14.42 percent. The global variable that affects the stability of Islamic banking in Pakistan is OIL. A negative OIL coefficient value is -1.25 , which means that an increase in OIL by 1 percent will reduce the stability level of Islamic banking in Pakistan by 1.25 percent. Fuel oil is one of the energy needs of a country, so countries that do not have sufficient crude oil will import to countries that have excess production of excess crude oil. This will result in importing countries dependent on exchange rates and dependence on volatility in oil prices. The impact of this volatility in oil prices, especially for importing countries, can cause fluctuations in the prices of goods and services in the country so that inflation will increase, which results in decreased purchasing power of the public and an increase in interest rates that have the possibility of default risk from debtors. These results are consistent with previous research by Zhuang (2005).

Unlike Indonesia and Malaysia, some Pakistan test results do not agree with the theory in general. In the case of the test results, this can happen. For the context of testing the partial significance of economic variables for the scale of the country as in this study, this can be due to the fact that, as is customary in policymaking in a country in the context of maintaining financial sector stability and productivity, the element of trade-off always appears. The behavioral characteristics of bank industry players, customers, policymakers, and regulators also determine the outcome of a policy taken or the impact of an economic 
variable on industrial and economic stability. For Pakistan, this is the case with CAR, NPF, FDR, and PR.

A negative CAR coefficient value is -19.17 , which means that an increase in CAR by 1 percent will reduce the stability of Islamic banking in Pakistan by 19.17 percent. This result is not following the theory in which the theory explains that the higher the CAR value, the stability of Islamic banking increases because the divider of Islamic banking capital, namely risk-weighted assets (RWA), is getting smaller.

A positive NPF coefficient is 3.16, which means that an increase in the NPF of 1 percent will increase the stability level of Islamic banking in Pakistan by 3.16 percent. This result is not following the theory which the theory explains that the higher the NPF value of a bank, the higher the level of bad credit will disrupt the bank's liquidity level.

A positive FDR coefficient value is 159.45 , which means that an increase in FDR of 1 percent will increase the stability level of Islamic banking in Pakistan by 159.45 percent. This result is not following the theory where the theory explains that the higher the FDR value of a bank indicates that the bank's liquidity capacity is getting lower because the amount of funds required for financing is getting bigger.

A positive PR coefficient value is 12.20 , which means that an increase in PR by 1 percent will increase the stability level of Islamic banking in Pakistan by 12.20 percent. This result contradicts the theory in which theory explains that high interest rates will lead to a slowdown in the financing, triggering the instability of Islamic banking.

\section{Crisis Periods}

In Markov switching research, the period of determining stability is part of the estimation results. Moreover, this study uses two-equation models to establish a stable and unstable period for the Islamic Banking equation model.

The estimation results of the Indonesian Islamic banking regime shift period are estimated based on the movements of the variables used in the study. Figure 3 is the Indonesian Islamic banking model by looking at the classification probability regime 1 and regime 2 (Table 6 ).

From Figure 3 and Table 6, there are two regimes, namely regime 1 and regime 2 . Regime 1 is a stable period, while regime 2 is an unstable period. Figure 3 and Table 6 shows that in the first year of the research period, namely 2008, Indonesian Islamic Banking was in regime 2 or experienced instability. This result is consistent with the economic conditions affected by the crisis caused by the subprime mortgage in the United States and hurt the Indonesian economy, including financial institutions such as banks. This impact was felt by Islamic banking up to the beginning of 2009, seen from the total assets of the Islamic banking industry. However, overall it experienced positive growth but experienced a slowdown.

According to a Bank Indonesia report (2009), the slowdown that occurred was influenced by conditions in the real sector, such as the continued sluggishness in the national economy, the lack of recovery in people's purchasing power, and high economic costs, which resulted in limiting business expansion and reducing consumption. Then in January 2009, the graph shows that Indonesian Islamic 
banking is in a stable condition, but this is still a regime shift process because, in February 2009, the graph returned to a regime of instability. However, from March 2009 to August 2010, Indonesian Islamic banking was in a stable period.

\section{Figure 3 Classification Probability of Indonesian Islamic Banking}

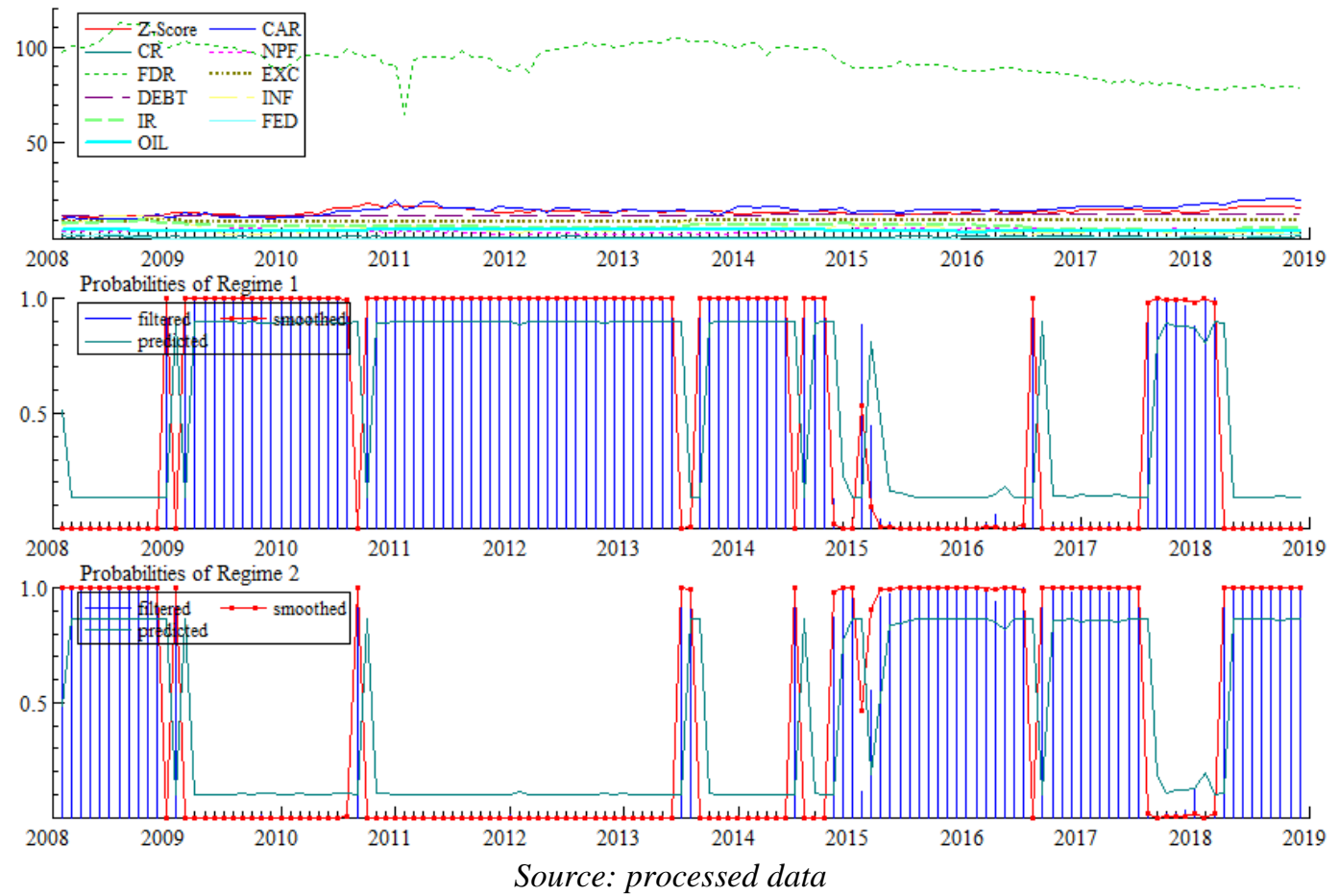

Table 6 Regime Classification of the Indonesian Islamic Banking

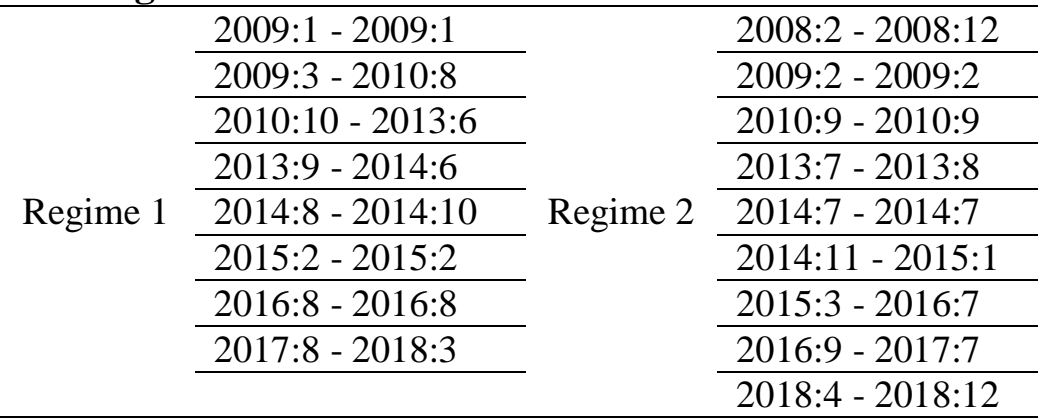

Source: processed data

It returned to an unstable period around September 2010 and returned to a stable period around October 2010 to June 2013. In the period from July 2013 to August 2013, Indonesian Islamic Banking returned to an unstable period. The period from September 2013 to June 2014 was stable, and July 2014 was in an unstable period. Then, August to October 2014 was in a stable period, and November 2014 to January 2015 was in an unstable period. In February 2015, it was in a stable period but returned to an unstable period, namely March 2015 to July 2016. Then it returned to a stable period for only 1 month, namely August 2016, and returned to an unstable period from September 2016 to July 2017. This continues following the economic cycle, from August 2017 to March 2018 in a stable period and April 2018 to December 2018 in an unstable period. 
Furthermore, it can be seen in the graph that 2019 is in regime 2, which means that economic conditions are predicted to be in instability in 2019. In the future, it will remain in an unstable condition until 2020, referring to the estimation data results from OxMetrics software.

If we look at the stability cycle of Indonesia's Islamic banking, from the end of 2015 to the end of 2018, it was in a period of instability. This is due to the slowdown in the world economy due to the Quantitative Easing policy implemented by the United States (US). In addition, this deceleration is influenced by cyclical factors and structural factors. Cyclical factors stemmed from the economic slowdown in China, the continued decline in commodity prices, and uncertainty over the normalization of US monetary policy.

The following is a graph of the Malaysian Islamic banking model by looking at the classification probability regime 1 and regime 2 . Figure 4 and Table 7 show that in the initial year of the study period, namely February 2008 to September 2008, Malaysian Islamic Banking was in regime 2 or experienced instability. This result is consistent with the economic conditions affected by the crisis caused by the subprime mortgage in the United States and negatively impacted the economies of developing countries, including Malaysia. According to the Economic Report of the Malaysian Ministry of Finance (2009), the slowdown that occurred was influenced by the US crisis, which resulted in tightening in the financial sector, especially credit. High inflation resulted in a decrease in household consumption resulted in an economic downturn.

Figure 4 Classification Probability of Malaysian Islamic Banking

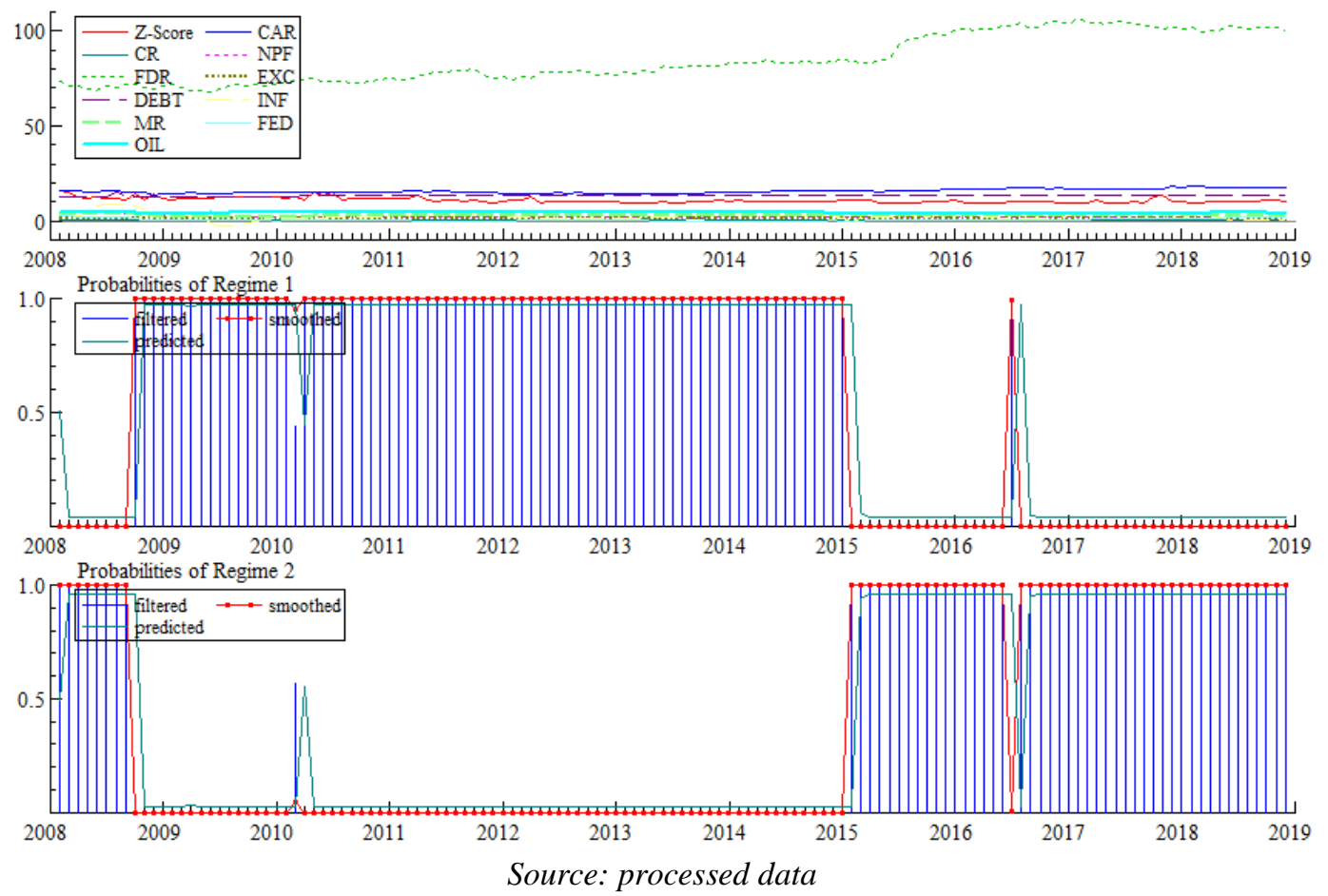


Table 7 Regime Classification of the Malaysian Islamic Banking

\begin{tabular}{|c|c|c|c|}
\hline \multirow{2}{*}{ Regime 1} & 2008:10 - 2015:1 & \multirow[b]{2}{*}{ Regime 2} & 2008:2 - 2008:9 \\
\hline & 2016:7 - 2016:7 & & $2015: 2-2016: 6$ \\
\hline
\end{tabular}

Source: processed data

Figure 4 and Table 7 can be seen from October 2008 to January 2015, showing that Malaysian Islamic banking was stable. However, from February 2015 to June 2016, Malaysian Islamic banking was in a period of instability. Then it was in a period of stability again, but it did not last long, only the period of July 2016, then the period of August 2016 to December 2018 was in instability. If we look at the stability cycle of Malaysian Islamic Banking, the end of 2015 to 2018 was in a period of instability. This is due to the slowdown in the world economy due to the Quantitative Easing policy implemented by the United States (US). In addition, this slowdown was influenced by high private and government debt in Malaysia, limited fiscal policies and sluggish employment. In addition, this slowdown was also caused by a slowdown in the global economy of developed countries such as the US, China and Europe (Economic Report of the Ministry of Finance of Malaysia 2015).

Figure 5 is a graph of the Pakistani Islamic banking model by looking at the classification probability regime 1 and regime 2. Figure 5 and Table 8 show that in the initial year of the study period, namely February 2008, it was stable. However, from March 2008 to September 2008, Pakistani Islamic Banking was in regime 2 or experienced instability. This result is consistent with the economic conditions affected by the crisis caused by the subprime mortgage in the United States and negatively impacted the economies of developing countries, including Pakistan.

\section{Figure 5 Classification Probability of Pakistani Islamic Banking}

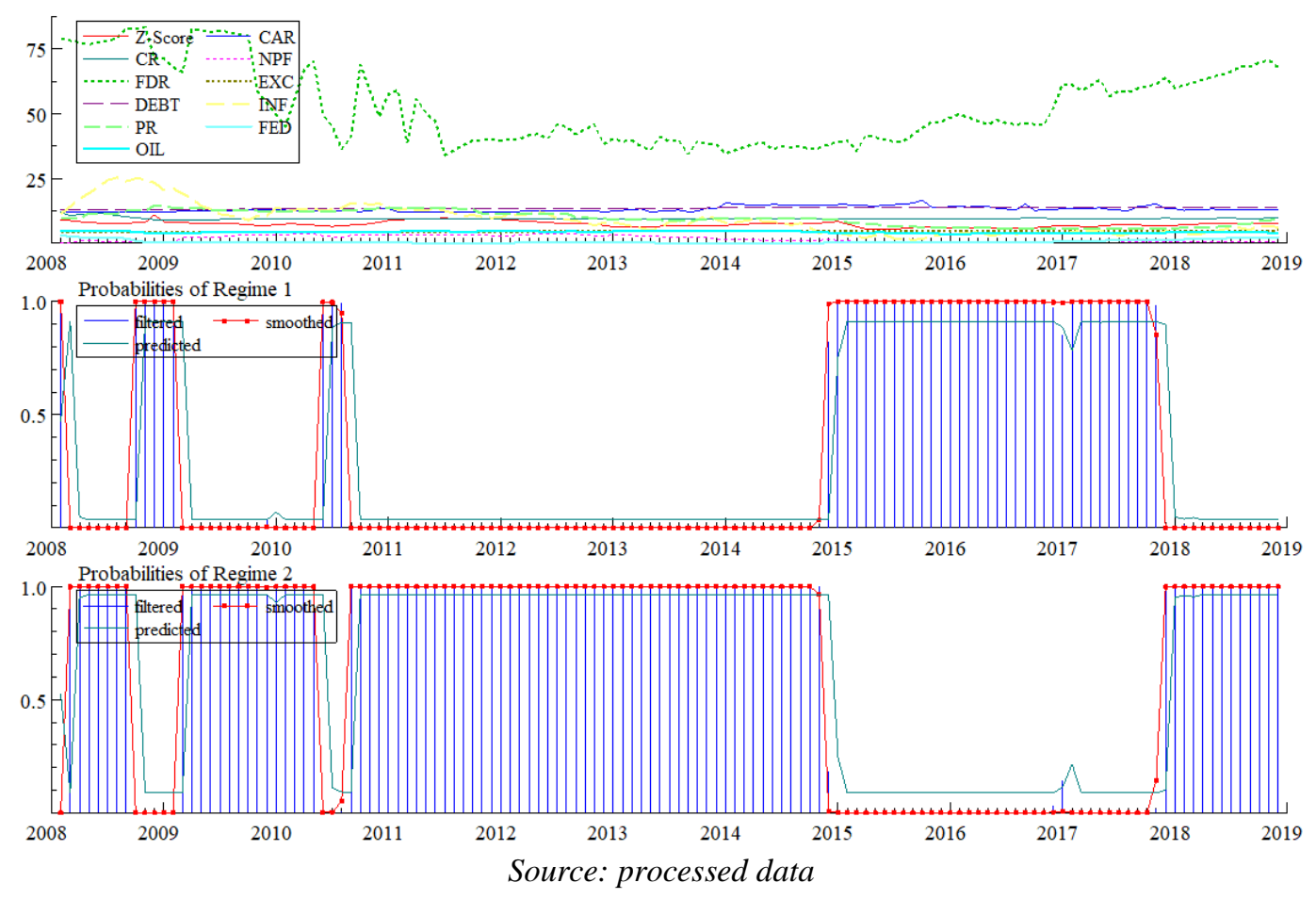


Table 8 Regime Classification of the Pakistani Islamic Banking

\begin{tabular}{|c|c|c|c|}
\hline \multirow{4}{*}{ Regime 1} & $2008: 2-2008: 2$ & \multirow{4}{*}{ Regime 2} & 2008:3 - 2008:9 \\
\hline & 2008:10 - 2009:2 & & $2009: 3-2010: 5$ \\
\hline & 2010:6 - 2010:8 & & 2010:9 - 2014:11 \\
\hline & 2014:12 - 2017:11 & & $2017: 12$ - 2018:12 \\
\hline
\end{tabular}

Source: processed data

Figure 5 and Table 8 can be seen from October 2008 to February 2009, Pakistani Islamic banking is stable. However, from March 2009 to May 2010, Pakistani Islamic banking is in a period of instability. Then it was in a period of stability again but did not last long, only the period from June 2020 to August 2010, then the period September 2010 to November 2014 was in instability. The last stable period of Islamic banking in Pakistan was December 2014 to November 2017, and the period December 2017 to December 2018 returned to a cycle of instability. If we look at the cycle of stability in Pakistani Islamic banking, there was a period of instability in the range of 2008 to 2015. This is due to the condition of the world economy, which was affected by instability after the subprime mortgage crisis, where the inflation rate and interest rates in Pakistan were very high.

Overall, the data from the crisis period shows that in the three countries studied in 2019, they entered the beginning of the crisis period, which means that the world conditions starting in 2019 tend to re-enter the crisis, repeating the conditions that occurred in 2008 and before. This condition is a condition that economic observers have predicted, such as the prediction of the financial crisis and global recession that will occur in 2020 (Roubini and Rosa 2018). In the same year, several parties also conveyed similar things, both financial institutions (Stubbly 2018) and financial practitioners (White 2018). The world economy would first expand in 2019, in line with the United States (US) policy to run a massive budget deficit. Meanwhile, China implemented loose fiscal and credit policies, and Europe is still in a recovery phase. However, the situation is not the same in the following year, and an economic crisis will occur. The crisis in 2020 will be more severe than the crisis in 2008. Unlike in 2008, when the government had the necessary policy tools to prevent free fall, policymakers in 2020 will be bound by a higher level of debt than the crisis in 2008 (Roubini and Rosa 2018).

\section{CONCLUSION}

The stability of Indonesian Islamic banking is more stable than the stability of Islamic banking in Malaysia and Pakistan. This is based on the results of processing the Z-Score data with ROA. The data in this study indicate that the average Z-Score of Indonesian Islamic Banking is higher than Malaysia and Pakistan. Based on economic variables, the level of economic influence on the stability of Islamic banking in Indonesia is smaller than in Malaysia and Pakistan. The results of the Partial Significance test show that there are five significant variables for the Indonesian Islamic Banking Model, six significant variables for Malaysia, and seven significant variables for Pakistan.

From the crisis periods determined in this research, the government as a regulator can take the necessary anticipatory and recovery steps to maintain national economic stability. Maintaining and restoring national economic stability 
must be pursued through comprehensive policy measures that involve the macroeconomic stabilization program, monetary and fiscal policies, and reform programs in the financial sector and the real sector. In facing possible crises in the future, regulators should be more careful in determining the country's economic policy direction. Considering that the economy has a cycle of instability, especially in the future, based on research into the approaching crisis period, solutions and adequate steps are needed to keep economic indicators stable. In dealing with the impact of the crisis, what the regulator needs to do immediately is restructure banks. The series of policies aimed at building public and foreign trust in the financial system and economy makes banking more solvable so that it can function again as an intermediary institution that encourages economic growth and increases the effectiveness of monetary policy implementation. Industry players should redefine business strategies for effective anticipatory measures in facing unstable economic conditions.

This study limits the analysis to the stability of Islamic banking against microeconomic and macroeconomic shocks in three countries, namely Indonesia, Malaysia, and Pakistan. The stability measurement variables used in this study are also limited to Capital Adequacy Ratio, Current Ratio, Non-Performing Financing, Financing to Deposit Ratio, Exchange Rate, Debt, Inflation, Interest Rate, FED Rate, and Oil Price. This research is expected to reference future researchers conducting similar studies by taking samples from other countries and different macroeconomic and microeconomic variables.

\section{REFERENCES}

Akhtar, Hameeda, Zaheer Abbas, and Ikramullah Toor. 2011. "Early Warning Signs of Forecast Financial Crisis in Pakistan". Interdisciplinary Journal of Contemporary Research in Business 2 (12). http://journalarchieves3.webs.com/april11.rar.

Allen, William, and Geoffrey Wood. 2005. "Defining and Achieving Financial Stability". LSE Financial Markets Group, Special Paper Series 160. https://econpapers.repec.org/paper/fmgfmgsps/sp160.htm.

Asanović, Željka. 2013. "Early Warning Models for Systemic Banking Crises in Montenegro". Economic and Business Review 15 (2), 135-149. https://www.proquest.com/openview/f43f66f3161d4225d6d61f5a58235bc e.

Ascarya, Ascarya, and Diana Yumanita. 2009. "Formulasi Indeks Stabilitas Keuangan Dan Peran Perbankan Syariah Dalam Sistem Keuangan Ganda di Indonesia". Working Paper Series. PPSK Bank Indonesia.

Ascarya, Ascarya, and F. Syarifuddin. 2012. "The Anatomy of Financial Crisis and how to Prevent it: The Case of Dual Financial System in Indonesia". BI Working Paper 2012 (19).

Barişik, Salih, and Arzu Tay. 2010. "An Analysis of Financial Crisis by Early Warning Approach: The Case of Transition Economies and Emerging Market (1994-2006 Period Panel Logit Model)". International Journal of Economic Perspectives 4 (2), 403-426.

Belouafi, Ahmed, Chaouki Achour Bourakba, and Karima Saci. 2015. "Islamic Finance and Financial Stability: A Review of the Literature". Journal of 
King Abdulaziz University: Islamic Economics 28 (2), 3-44. https://ssrn.com/abstract=3063842.

Borman, Sean. 2004. "The Expectation Maximization Algorithm a Short Tutorial". http://people.csail.mit.edu/dsontag/courses/ml14/slides/EM_algorithm.pdf.

Boyd, John H., Gianni De Nicolo, and Abu M. Jalal. 2009. "Bank Competition, Risk and Aseet Allocations". IMF Working Paper 2009 (143), 35. https://doi.org/10.5089/9781451872903.001.

Čihák, Martin. 2006. "How Do Central Banks Write on Financial Stability?" IMF Working Paper 06 (163). https://ssrn.com/abstract=920255.

Čihák, Martin, and Heiko Hesse. 2010 "Islamic Banks and Financial Stability: An Empirical Analysis". Journal of Financial Services Research 38, 95113. https://doi.org/10.1007/s10693-010-0089-0.

Crockett, Andrew. 1996. "The Theory and Practice of Financial Stability". De Economist 144, 531-568. https://doi.org/10.1007/BF01371939.

Davis, E. Philip. 2003. "Towards a Typology for Systemic Financial Instability”. Economics and Finance Working papers, Brunel University 03-20. http://bura.brunel.ac.uk/handle/2438/916.

Gujarati, Damodar N. 2003. Basic Econometrics, Fourth Edition. New York: McGraw-Hill.

Hamilton, James D. 1990. "Analysis of Time Series Subject to Changes in Regime". Journal of Econometrics 45 (1-2), 39-70. https://doi.org/10.1016/0304-4076(90)90093-9.

Hagen, Jürgen Von, and Tai-Kuang Ho. 2007. "Money Market Pressure and Determinant of Banking Crises". Journal of Money, Credit and Banking 39 (5), 1037-1066. https://doi.org/10.1111/j.1538-4616.2007.00057.x.

Hardy, Daniel C., and Ceyla Pazarbaşioğlu. 1998. "Leading Indicators of Banking Crises: Was Asia Different?" IMF Working Paper 98/91. https://ssrn.com/abstract=882602.

Hardy, Daniel C., and Ceyla Pazarbaşioğlu. 1999 "Determinant and Leading Indicators of Banking Crises: Further Evidence". IMF Staff Papers 46, 247-258. https://doi.org/10.2307/3867642.

Hidayat, Sutan Emir, and Muhamad Abduh. 2012. "Does Financial Crisis Give Impacts on Bahrain Islamic Banking Performance? A Panel Regression Analysis". International Journal of Economic and Finance 4 (7), 79-87. https://doi.org/10.5539/ijef.v4n7p79.

Hosni, Khaoula. 2014. "Early Warning Indicators for Systemic Banking Crises". Journal of Business Studies Quarterly 5 (4), 222-244. https://www.proquest.com/openview/e93e46a9afbbfb8697e94e6449fa5e4d

Houben, Aerdt, Jan Kakes, and Garry J. Schinasi. 2004. "Toward A Framework For Safeguarding Financial Stability". IMF Working Papers WP/04/101. https://www.imf.org/external/pubs/ft/wp/2004/wp04101.pdf.

Issing, Othmar. 2003. "Monetary and Financial Stability: Is There a Trade-Off?". Bank for International Settlements (BIS) Paper 18, 16-23. https://www.bis.org/review/r030331f.pdf.

Kaminsky, Graciela L., and Carmen M. Reinhart. 1999. "The Twin Crises: The Causes of Banking and Balance-of-Payments Problems". American $\begin{array}{lllll}\text { Economic } & \text { Review } & 89 & \text { (3), }\end{array}$ https://www.doi.org/10.1257/aer.89.3.473. 
Kassim, Salina H., and M. Shabri Abd. Majid. 2010. "Impact of Financial Shocks on Islamic Bank Malaysia Evidence during 1997 and 2007 Financial Crises". International Journal of Islamic and Middle Eastern Finance and Management 3 (4), 291-305. https://doi.org/10.1108/17538391011093243.

Krolzig, Hans-Martin. 1997. "The Markov-Switching Vector Autoregressive Model". In: Markov-Switching Vector Autoregressions. Lecture Notes in Economics and Mathematical Systems 454, 6-28. https://doi.org/10.1007/978-3-642-51684-9_2

Mishkin, Frederic S. 2012. The Economics of Money, Banking and Financial Markets, Tenth Edition, International Edition. New York: Pearson Addison Wesley Longman.

Mukhlisin, Murniati, and Ratna Komalasari. 2018. "Do You Capture Financial Crisis?". Journal of Islamic Monetary Economics and Finance 3 (2), 245292. https://doi.org/10.21098/jimf.v3i2.892.

Nurfalah, Irfan, Aam Slamet Rusydiana, Nisful Laila, and Eko Fajar Cahyono. 2018. "Early Warning to Banking Crises in the Dual Financial System in Indonesia: The Markov Switching Approach". Journal of King Abdulaziz University: $\quad$ Islamic Economics $31 \quad$ (2), 133-156. https://www.doi.org/10.4197/Islec.31-2.10.

Rahim, Siti Rohaya Mat, and Roza Hazli Zakaria. 2013 "Comparison on Stability Between Islamic and Conventional Banks in Malaysia". Journal of Islamic Economics, Banking and Finance 9 (3), 131-149. https://doi.org/10.12816/0001618.

Roubini, Nouriel, and Brunello Rosa. 2018. "The Makings of a 2020 Recession and Financial Crisis". Project Syndicate. https://www.projectsyndicate.org/commentary/financial-crisis-in-2020-worse-than-2008-bynouriel-roubini-and-brunello-rosa-2018-09.

Schinasi, Garry J. 2004. "Defining Financial Stability". IMF Working Paper WP/04/187. https://www.imf.org/external/pubs/ft/wp/2004/wp04187.pdf.

Stubbly, Peter. 2018. Next Global Financial Crisis Will Strike In 2020, Warns Investment Bank JPMorgan. Independent. https://www.independent.co.uk/news/business/news/next-financial-crisis2020-recession-world-markets-jpmorgan-a8540341.html.

Vargas, Gregorio III Alfredo. 2009. Markov Switching Var Model of Speculative Pressure: An Application to the Asian Financial Crisis. Thesis Singapore Management University. https://ink.library.smu.edu.sg/etd_coll/27/.

White, William. 2018. Bad Financial Moon Rising. Project Syndicate. https://www.project-syndicate.org/commentary/global-economy-weakfundamentals-by-william-white-2018-10.

Zahra, Siti Fatimah, Ascarya Ascarya, and Nurul Huda. 2018. "Stability Measurement of Dual Banking System in Indonesia: Markov Switching Approach". Al-Iqtishad: Jurnal Ilmu Ekonomi Syariah 10 (1), 25-52. http://dx.doi.org/10.15408/aiq.v10i1.5867.

Zhuang, Juzhong. 2005. Nonparametric EWS Models of Currency and Banking Crises for East Asia. In: Asian Development Bank (eds) Early Warning Systems for Financial Crises, 39-122. London: Palgrave Macmillan. https://doi.org/10.1057/9780230501065_4. 


\section{APPENDICES}

Appendix 1 Stationarity Test of Indonesian Islamic Banking
\begin{tabular}{|c|c|c|c|c|}
\hline \multirow{2}{*}{ Variable } & \multicolumn{2}{|c|}{ ADF Value } & \multicolumn{2}{c|}{ PP Value } \\
\cline { 2 - 5 } & Level & $\mathbf{1}^{\text {st }}$ Diff & Level & $\mathbf{1}^{\text {st }}$ Diff \\
\hline Zscore & $-2,6666$ & $\mathbf{- 1 4 , 4 2 3 1}$ & $-2,5937$ & $\mathbf{- 1 4 , 3 0 3 6}$ \\
\hline CAR & $-0,9028$ & $\mathbf{- 1 2 , 4 5 7 4}$ & $-1,8836$ & $\mathbf{- 1 5 , 5 9 7 9}$ \\
\hline CR & $\mathbf{- 6 , 4 0 4 7}$ & $\mathbf{- 4 , 3 1 4 9}$ & $\mathbf{- 6 , 4 6 4 7}$ & $\mathbf{- 2 6 , 4 9 1 3}$ \\
\hline NPF & $-1,8818$ & $\mathbf{- 3 , 5 8 9 3}$ & $-1,9142$ & $\mathbf{- 1 4 , 1 3 3 6}$ \\
\hline FDR & $-1,5341$ & $\mathbf{- 1 6 , 3 2 6 7}$ & $-2,0260$ & $\mathbf{- 1 7 , 9 3 5 8}$ \\
\hline EXC & $-0,6357$ & $\mathbf{- 1 0 , 0 0 8 5}$ & $-0,7710$ & $\mathbf{- 1 0 , 0 0 2 2}$ \\
\hline DEBT & $-2,3069$ & $\mathbf{- 1 2 , 7 3 4 8}$ & $-2,6583$ & $\mathbf{- 1 2 , 7 1 6 4}$ \\
\hline INF & $-2,5109$ & $\mathbf{- 7 , 4 4 1 9}$ & $-2,2204$ & $\mathbf{- 7 , 5 2 1 8}$ \\
\hline IR & $-2,1682$ & $\mathbf{- 4 , 7 8 5 0}$ & $-1,8245$ & $\mathbf{- 7 , 5 9 9 1}$ \\
\hline
\end{tabular}

Note: The ones printed in bold are significant at the real level of $5 \%$

\begin{tabular}{|c|c|c|c|c|}
\multicolumn{4}{|c|}{ Appendix 2 Stationarity Test of Malaysian Islamic Banking } \\
\hline \multirow{2}{*}{ Variable } & \multicolumn{2}{|c|}{ ADF Value } & \multicolumn{2}{c|}{ PP Value } \\
\cline { 2 - 5 } & Level & $\mathbf{1}^{\text {st }}$ Diff & Level & $\mathbf{1}^{\text {st }}$ Diff \\
\hline Zscore & $\mathbf{- 4 , 1 3 1 2}$ & $\mathbf{- 8 , 3 3 8 0}$ & $\mathbf{- 4 , 6 6 4 4}$ & $\mathbf{- 2 7 , 3 8 3 8}$ \\
\hline CAR & $-0,9587$ & $\mathbf{- 1 2 , 9 1 0 7}$ & $-0,6542$ & $\mathbf{- 1 3 , 2 1 3 5}$ \\
\hline CR & $\mathbf{- 4 , 6 9 3 2}$ & $\mathbf{- 8 , 6 8 9 0}$ & $\mathbf{- 4 , 5 5 1 3}$ & $\mathbf{- 3 4 , 3 3 2 2}$ \\
\hline NPF & $\mathbf{- 5 , 8 6 8 7}$ & $\mathbf{- 9 , 9 9 5 9}$ & $\mathbf{- 5 , 1 3 5 4}$ & $\mathbf{- 1 4 , 3 0 9 0}$ \\
\hline FDR & $-0,3577$ & $\mathbf{- 1 1 , 3 4 5 3}$ & $-0,4028$ & $\mathbf{- 1 1 , 3 5 3 7}$ \\
\hline EXC & $-0,8641$ & $\mathbf{- 1 1 , 5 1 4 6}$ & $-0,8641$ & $\mathbf{- 1 1 , 5 1 4 5}$ \\
\hline DEBT & $-2,1669$ & $\mathbf{- 1 3 , 6 4 4 0}$ & $\mathbf{- 5 , 4 1 7 7}$ & $\mathbf{- 1 0 2 , 1 6 4 9}$ \\
\hline INF & $\mathbf{- 3 , 7 1 8 2}$ & $\mathbf{- 7 , 3 1 7 5}$ & $\mathbf{- 2 , 9 5 5 3}$ & $\mathbf{- 7 , 2 5 6 0}$ \\
\hline MR & $\mathbf{- 3 , 6 3 6 7}$ & $\mathbf{- 1 0 , 9 5 8 1}$ & $\mathbf{- 3 , 4 0 9 8}$ & $\mathbf{- 1 2 , 2 4 5 4}$ \\
\hline
\end{tabular}

Note: The ones printed in bold are significant at the real level of $5 \%$

\begin{tabular}{|c|c|c|c|c|}
\hline \multirow{2}{*}{ Appendix 3 Stationarity Test of Pakistani Islamic Banking } \\
\hline \multirow{2}{*}{ Variable } & \multicolumn{2}{|c|}{ ADF Value } & \multicolumn{2}{c|}{ PP Value } \\
\cline { 2 - 5 } & Level & $\mathbf{1}^{\text {st }}$ Diff & Level & $\mathbf{1}^{\text {st }}$ Diff \\
\hline Zscore & $-1,9636$ & $\mathbf{- 6 , 3 7 5 1}$ & $-1,7061$ & $\mathbf{- 1 0 , 6 0 4 4}$ \\
\hline CAR & $-2,6583$ & $\mathbf{- 1 4 , 9 3 8 9}$ & $\mathbf{- 3 , 0 9 3 0}$ & $\mathbf{- 1 9 , 6 8 3 2}$ \\
\hline CR & $\mathbf{- 3 , 0 5 5 9}$ & $\mathbf{- 7 , 6 8 0 2}$ & $\mathbf{- 4 , 4 2 7 8}$ & $\mathbf{- 1 1 , 8 4 2 5}$ \\
\hline NPF & $-2,6323$ & $\mathbf{- 4 , 8 5 8 8}$ & $\mathbf{- 1 1 , 4 4 5 9}$ & $\mathbf{- 7 7 , 4 0 7 7}$ \\
\hline FDR & $-1,3276$ & $\mathbf{- 9 , 5 4 0 3}$ & $\mathbf{- 2 , 9 3 8 2}$ & $\mathbf{- 7 3 , 0 2 3 5}$ \\
\hline EXC & $-1,0654$ & $\mathbf{- 4 , 1 5 9 8}$ & $-1,1729$ & $\mathbf{- 9 , 3 9 5 2}$ \\
\hline DEBT & $-2,6878$ & $\mathbf{- 1 2 , 5 5 8 3}$ & $-1,8552$ & $\mathbf{- 1 2 , 5 2 8 2}$ \\
\hline INF & $-2,3038$ & $\mathbf{- 7 , 4 4 2 6}$ & $-1,5965$ & $\mathbf{- 8 , 5 2 4 2}$ \\
\hline PR & $-1,8155$ & $\mathbf{- 3 , 0 9 2 1}$ & $-1,2090$ & $\mathbf{- 1 1 , 6 0 1 5}$ \\
\hline
\end{tabular}

Note: The ones printed in bold are significant at the real level of $5 \%$

Appendix 4 Heteroscedasticity Test of Indonesian Islamic Banking

\begin{tabular}{|l|r|l|l|}
\hline F-statistic & 1,3244 & Prob. F(10,121) & $\mathbf{0 . 2 2 5 0}$ \\
\hline Obs*R-square & 13,0230 & Prob. Chi-Square(10) & 0.2224 \\
Scale explained SS & 17,4689 & Prob. Chi-Square(10) & 0.0646 \\
\hline
\end{tabular}

Note: The ones printed in bold are significant at the real level of $5 \%$

Appendix 5 Heteroscedasticity Test of Malaysian Islamic Banking

\begin{tabular}{|l|r|l|r|}
\hline F-statistic & 1,2525 & Prob. F(10,121) & $\mathbf{0 . 2 6 5 1}$ \\
\hline Obs*R-square & 12,3820 & Prob. Chi-Square(10) & 0.2603 \\
Scale explained SS & 28,6091 & Prob. Chi-Square(10) & 0.0014 \\
\hline \multicolumn{4}{|c|}{ Note: The ones printed in bold are significant at the real level of 5\% }
\end{tabular}

Note: The ones printed in bold are significant at the real level of 5\%

Appendix 6 Heteroscedasticity Test of Pakistani Islamic Banking

\begin{tabular}{|l|r|l|r|}
\hline F-statistic & 1,6702 & Prob. F(10,121) & $\mathbf{0 . 0 9 5 3}$ \\
\hline Obs*R-square & 16,0110 & Prob. Chi-Square(10) & 0.0993 \\
Scale explained SS & 18,1928 & Prob. Chi-Square(10) & 0.0518 \\
\hline
\end{tabular}

Note: The ones printed in bold are significant at the real level of $5 \%$
Appendix 7 Chow Breakpoint Test of Indonesian Islamic Banking \begin{tabular}{|l|r|l|r|}
\hline F-statistic & 9,55 & Prob. F(12,108) & $\mathbf{0 . 0 0}$ \\
\hline Log likelihood ratio & 88,52 & Prob. Chi-Square(12) & 0.00
\end{tabular} \begin{tabular}{l|l|l|l} 
Wald Statistic & 105,10 & Prob. Chi-Square(12) & 0.00
\end{tabular}

Note: The ones printed in bold are significant at the real level of $5 \%$

Appendix 8 Chow Breakpoint Test of Malaysian Islamic Banking \begin{tabular}{|l|l|l|l|}
\hline F-statistic & 3,07 & Prob. F(12,108) & $\mathbf{0 . 0 0 1 2}$ \\
\hline
\end{tabular} \begin{tabular}{|l|c|l|l|}
\hline Log likelihood ratio & 35,42 & Prob. Chi-Square(12) & 0.0002
\end{tabular} \begin{tabular}{|l|l|l|l|} 
Wald Statistic & 33,85 & Prob. Chi-Square(12) & 0.0004 \\
\hline
\end{tabular} Note: The ones printed in bold are significant at the real level of $5 \%$

Appendix 9 Chow Breakpoint Test of Pakistani Islamic Banking \begin{tabular}{|l|r|l|l|}
\hline F-statistic & 4,52 & Prob. F(12,108) & $\mathbf{0 . 0 0}$ \\
\hline Log likelihood ratio & 49,23 & Prob. Chi-Square(12) & 0.00 \\
Wald Statistic & 49,72 & Prob. Chi-Square(12) & 0.00 \\
\hline
\end{tabular}

Note: The ones printed in bold are significant at the real level of $5 \%$

Appendix 10 EM Algorithm Test of Indonesian Islamic Banking

\begin{tabular}{|c|c|}
\hline Log-Likelihood & 498,0658 \\
\hline AIC Criterion & $-3,3750$ \\
\hline HQ Criterion & $-0,9046$ \\
\hline SC Criterion & 2,7046 \\
\hline LR Linearity Test & 383,0006 \\
\hline Chi (77) & $\mathbf{0 , 0 0}$ \\
\hline Chi (79) & $\mathbf{0 , 0 0}$ \\
\hline DAVIES & $\mathbf{0 , 0 0}$ \\
\hline
\end{tabular}

Appendix 11 EM Algorithm Test of Malaysian Islamic Banking

\begin{tabular}{|c|c|}
\hline Log-Likelihood & 421,0095 \\
\hline AIC Criterion & $-3,2063$ \\
\hline HQ Criterion & $-1,3245$ \\
\hline SC Criterion & 1,4248 \\
\hline LR Linearity Test & 69,7345 \\
\hline Chi (77) & $\mathbf{0 , 0 0}$ \\
\hline Chi (79) & $\mathbf{0 , 0 0}$ \\
\hline DAVIES & $\mathbf{0 , 0 0}$ \\
\hline
\end{tabular}

Appendix 12 EM Algorithm Test of Pakistani Islamic Banking

\begin{tabular}{|c|c|}
\hline Log-Likelihood & 413,9915 \\
\hline AIC Criterion & $-3,0991$ \\
\hline HQ Criterion & $-1,2173$ \\
\hline SC Criterion & 1,5319 \\
\hline LR Linearity Test & 53,7876 \\
\hline Chi (77) & $\mathbf{0 , 0 0}$ \\
\hline Chi (79) & $\mathbf{0 , 0 0}$ \\
\hline DAVIES & $\mathbf{0 , 0 0}$ \\
\hline
\end{tabular}

